\title{
Citizens' Policy Mood, Policies and Election Outcomes in Italy
}

\author{
Paolo Bellucci and Alessandro Pellegata
}

\begin{abstract}
This article investigates the relationship between changes in Italians' policy preferences and parties' and governments' responsiveness. It analyses whether there is a congruence between citizens' policy preferences, on one side, and parties' and governments' ideological positions on the other. The study represents the first attempt to estimate the Italian 'policy mood' adopting a methodology already used for other political systems. We infer public preferences from more than 200 survey questions, administered more than 550 times between 1981 and 2015, which ask respondents to 'take a side' on several controversial domestic policy issues. Empirical results sustain the idea that public opinion acts as a thermostat to balance governments' policy goals; and, at the same time, they provide somewhat stronger evidence for the argument that governments adapt their preferences to changes in public opinion. Finally, it is shown that there is a relationship between citizens' preferences and their voting choices.
\end{abstract}

Keywords: Electoral behaviour; Ideology; Italy; Policy mood 


\section{Introduction}

Representative democracies base their legitimacy both on procedural norms enabling people freely to select their representatives, and on expectations of the substantive responsiveness of representatives to people's preferences. Specifically, democratic theories claim that, in democracies, people's preferences are translated into policy decisions. The correct functioning of the chain of responsiveness then implies that the preferences of decisionmakers converge to some extent on the preferences of the people on most controversial policy issues (Powell 2000).

In a cycle of representation, people's policy preferences are supposed to be exogenous to the political system, depending on socio-economic circumstances and other contextual factors. At the same time, government policies impact upon citizens and do help to mould popular preferences. Furthermore, citizens' lack of knowledge and interest (Delli Carpini and Keeter, 1989) mean that they also take cues on many issues from parties and leaders in forming preferences. Representation is therefore a circular process whereby preferences originate from the interaction of public opinion and political representatives. The topic of (policy) representation has however mainly seen scholars in turn focusing either on the leadership role played by elected representatives and parties - whom people seemingly follow - or on the primacy of popular preferences which parties apparently accommodate under the threat of electoral defeat. From a principal-agent perspective, then, the two roles would appear to alternate in providing answers to the questions: Who is leading? Who is following?

Research assigning the principal role to institutions (parties, governments, legislatures) focuses on policy feedbacks, that is, the consequences of policies for those affected by them, i.e., citizens. Enacted policies alter the behaviour and attitudes of the public by creating new constituencies, different patterns of political mobilisation and new priorities which in turn affect people's political behaviour and their preferences (see, for a review, Campbell; 2012). 
On the other hand, research focusing on the primacy of the people highlights how parties shift their policy positions in response to - among other factors - voters' changing policy preferences in a process of dynamic representation (for a review, see Stimson et al. 1995; Burstein, 2003, and Adams, 2012).

This literature recognises, however, the methodologically thorny issues about inference and causality - leaving aside for the moment the issue of how to measure people's preferences and parties' policies - and the demanding research designs and time series data required to ascertain patterns of causal variation (Hobolt and Klemmemsen, 2005). Although representation is seen as an iterative process in which policy positions result from the interplay of people's preferences and parties' priorities, the actual working of this interplay is a matter of theoretical and empirical debate, where the 'adaptive public' perspective has gained some prominence: research by Wlezien (1995; 2004) and Soroka and Wlezien (2005) frames public opinion as a 'thermostat', reacting adaptively to the status quo. That is, people demand less of a policy when its supply is high and vice versa. So public opinion and government policy are thought to move in tandem with preferences travelling in opposite directions.

In this article we undertake two tasks: the first involves providing for the Italian case a summary measure of the public's policy preferences and tracking it over time, from 1981 to 2015. To infer citizens' policy preferences we do not rely on their reported positions on the left-right scale, but we estimate them from more than 200 survey questions - administered more than 550 times between 1981 and 2015 - which ask respondents to 'take a side' on several controversial domestic policy issues. This is a first attempt to assess the Italian domestic 'policy mood', a macro-level estimation of the public's policy preferences, adopting methods already tested in the US (Stimson 1999), Great Britain (Bartle, DellepianeAvellaneda 2010), France (Stimson, Thiébault and Tiberj 2012) and Spain (Bartle, Bosch and 
Orriols 2014). The second task we pursue is the assessment of some of the interactions between public opinion and parties. We do so by exploring: a) whether public opinion reacts to parties' and governments' policy preferences; b) whether governments' policies are responsive to changing popular preferences; c) whether, finally, people's policy preferences have an electoral impact. The paper is then organised as follows: in the next section we discuss the measure of the public's policy preferences - the policy mood - and track its change over time; in the following section we test two leading hypotheses in the literature: that public opinion reacts to government policies and that political actors are responsive to people's preferences; in the fourth section we assess the electoral impact of the policy mood, while the conclusion summarises the findings.

\section{The Structure of Policy Preferences: The Italian Policy Mood}

The relationship between political parties (and governments) on the one hand, and the electorate on the other is a cornerstone of representative democracy. In the last twenty years many efforts have been made to estimate, through different methodologies - from content analysis of party manifestoes to evaluations by policy experts - the positions of parties on several policy issues and in particular on the general left-right continuum (see among others, Laver and Hunt 1992; Budge et al. 2001; Benoit and Laver 2006; Klingemann 2006). By contrast, to track the movement over time of the electorate's preferences scholars have usually relied on citizens' self-placement on the left-right spectrum. This represents the most obvious way to infer the electorate's preferences. However, this method has several shortcomings, at the individual level at least. The first and foremost concern is that the question simply asks voters to locate themselves on a general left-right scale and such placements do not express clear preferences over policy outcomes. Such a question refers to the labels 'left' and 'right' to which people may attach themselves. Secondly, as several studies have argued, while the small group of politically sophisticated voters may use these labels correctly, the great 
majority of citizens may be uncertain as to the meaning of these labels, inferring their leftright position from the location of their preferred party (Scarbrough 1984; Box-Steffensmeier and De Boef 2001; Baldassarri 2007). Finally, the meaning of the 'left' and 'right' labels varies across countries and over time (Stimson 2004; Corbetta, Cavazza and Roccato- 2009).

Another feasible strategy is to estimate the citizens' preferences over a series of specific 'policy issues'. Policy issues are debates around valued alternatives, about 'what ought to be done' and the proper role of the government in managing public issues (Stimson 1999). They involve disagreement about the desirability of goals, such as state intervention in the economy versus the free market, or abortion rights versus protection of the unborn child. Taking a position implies that citizens express a preference, that they 'take a side'. The key concept of 'policy mood' in this literature is precisely a macro-level estimation of the citizens' opinions on several policy issues. It represents the shared feelings concerning policy preferences of individuals, which moves over time and according to circumstances (Stimson 1999; 2004). Whereas individual preferences may not be consistent and stable, the aggregate public opinion, if correctly measured, shows stability and predictability, allowing us to take marginal changes seriously. Thus, the policy-mood concept rests on the idea that the aggregation of variables, obtained by responses to questions in specific domains, cuts out inessential details and allows scholars to examine the relationship between preferences and policies and vice versa (Bartle, Dellepiane-Avellaneda and Stimson 2010).

To estimate the macro-level annual policy preferences, we started by compiling a dataset consisting of frequency distributions of responses to survey questions related to policy issues taken from nationally representative polls between 1981 and $2015 .{ }^{1}$ The data simply record the proportion of respondents who take sides on controversial policy issues 'supporting' or 'opposing' specific proposals and the role government should play in managing them, and the proportions 'agreeing' or 'disagreeing' with social, economic and political statements. Given 
that the statistical method adopted uses longitudinal evidence of change in marginal responses to estimate the policy mood, we included in the dataset only those questions that were asked using exactly the same wording in at least two separate years. We treated any differences in question wording, order, filter and response categories as different items. We excluded all those questions that referred to specific leaders, parties and governments, because from these questions is not possible to disentangle citizens' opinions on government activity and their judgements of either politicians, parties or cabinets.

The data were collected from eight survey programmes: Eurobarometer (EB), European Quality of Life Survey (EQLS), European Social Survey (ESS), European Values Study (EVS), International Social Survey Program (ISSP), Italian National Election Studies (ITANES), Pew Research Centre (PEW) and World Values Surveys (WVS). Table A1 in the Appendix shows the number and proportion of single questions and the administration of these questions for all eight survey programmes used as data sources. The full dataset includes a total of 251 single questions and 966 administrations. There are questions that specifically refer to domestic policy issues in different domains, such as public versus private ownership, inflation and unemployment, moral and social attitudes, ethnic relations and immigration. In general, this type of questions clearly invites respondents to endorse controversial goals and take a side by selecting a 'left-' or 'right-wing' option. Thus it was quite a simple task to decide the directional thrust of the responses and attribute them to a latent left-right scale. Considering that party politics is structured in left-right terms, survey designers take note of this aspect and frame survey items accordingly, mostly concerning the standard positions of parties. Mistakes (i.e., incorrect polarities of the coding) while not affecting the estimation, would reveal incorrect signed factor loadings, alerting the researcher to the coding scheme and enabling him/her to correct it (see Stimson 1999; Bartle, Dellepiane-Avellaneda and Stimson 2010; Stimson, Thiébaut and Tiberj 2012). 
The full dataset also includes questions on citizens' attitudes toward European Union institutions, mainly taken from the Eurobarometer series, and questions on international affairs, mainly gathered from the Pew Research Centre. US studies on policy mood only include questions on domestic policy issues arguing that international affairs are unrelated to them (Stimson 1999; Erikson, MacKuen and Stimson 2002). However, we need to recognise that international issues, especially during the so called First Republic (1946-1993), historically divided the major parties and in some sense conditioned their domestic strategies. The Italian Communist Party (Partito Comunista Italiano, PCI), the largest communist party in Western Europe, was overtly pro-Soviet Union, whereas the Christian Democratic Party (Democrazia Cristiana, DC), which was permanently in government from 1946 to 1994, was pro-US. Although this argument is seemingly plausible, and inclusion of the international affairs questions does not significantly affect the estimation of the policy mood, we preferred to exclude them from the dataset.

We faced more severe problems with questions dealing with the EU issue. Undoubtedly, since the outbreak of the sovereign debt crisis in 2009, EU institutions and governance have become extremely controversial issues, thanks especially to the constraints they impose on member states' economic policies. Nevertheless, it was particularly difficult to locate citizens' responses to questions on EU issues on the left-right spectrum. Italian citizens' and parties' attitudes toward the EU changed over time (Bellucci and Conti, 2012). Among those that more strongly oppose the EU model of governance and the Euro we can find citizens and parties located both on the left and the right of the continuum, as well as citizens and parties that cannot be easily located on it (see, for instance, the Five-star Movement (Movimento 5 Stelle, M5S) and their voters). Therefore, in this preliminary research effort we preferred also to exclude questions on EU issues from our analysis. This choice was also motivated by an empirical concern. In the full dataset questions on EU issues 
are among the ones administered almost every year. Given their longer series, these questions have highly relevant predictive power in inferring the policy mood. Including them in the analysis would imply that the estimated policy mood would be strongly affected by citizens' responses to questions on EU issues. Finally, for the reason explained at the beginning of this section we decided also to exclude questions on citizens' left-right self-placement, and to use the series generated from these items only to validate our extracted estimation of the domestic policy mood.

The final dataset used for analysis of the domestic policy mood includes a total of 202 questions for 554 administrations over the 1981-2015 period (see the last two columns of Table A1 in the Appendix). The ISSP survey programme contributes to the dataset with almost one third of the questions and administrations, while two other programmes - ITANES and EVS - contribute with almost one fifth of the administrations. The peak of survey administrations is in $2006(\mathrm{~N}=84)$, followed by $1990(\mathrm{~N}=66), 2013(\mathrm{~N}=63), 1999(\mathrm{~N}=47)$ and 2012 (N=47). Once we had coded respondents' marginals as either 'left', 'right' or 'neutral', we then computed an 'Index of Preferences' measuring the proportion of 'leftist' preferences over the total of respondents' preferences, excluding neutral ones. ${ }^{2}$ The formula is the following:

$$
\text { Index of Preferences }=\frac{\sum_{i=1}^{N}(\text { Left Preferences })}{\sum_{I=1}^{N}(\text { Left }+ \text { Right Preferences })}
$$

Preferences vary across individuals and over time. The index of preferences allows us to aggregate individual preferences for each single item. We cannot, however, simply average preferences for different years. Items included in the dataset belong to different policy issues that might help to define different dimensions. Some items and issues are better indicators of left-right positions than others. Moreover, the same issues are often measured using several items that have different wording and response categories. Principal components analysis 
could be the solution to analyse changes in preferences over time, but it is not workable given the structure of the public opinion data. The reason is that what we have are survey items repeated a few times over the long period we want to investigate. Therefore, most of the possible cases, i.e. the answers to a survey question in year $t$, are missing. Missing cases considerably outnumber observed cases and imputing values for all those missing cases would create a dangerous dependence on the assumption underlying the imputation (Stimson 1999; Bartle, Dellepiane-Avellaneda and Stimson 2010). This is the reason why we adopted the 'dyad ratio algorithm', an estimation technique that is modelled on the same assumptions as principal components analysis but allows us to aggregate preference data across individuals, first, and then across different items, coping with the problem of missing data (Stimson 1999; Bartle, Dellepiane-Avellaneda and Stimson 2010; Bartle, Bosch and Orriols 2014). The solution to this problem is to express preferences as ratios of responses to the same question asked at different times. The extraction algorithm calculates these ratios recursively for every possible dyad until information at all time points has been exhausted (Stimson 1999). These ratios, finally, can be averaged for each year to provide an indicator of average preferences. ${ }^{3}$

Figure 1 plots our estimate of the Italian domestic policy mood. The measure presents the same metric of the input data, i.e. the index of preferences. The policy mood basically measures the proportion of citizens that have 'left-wing' preferences. It ranges from 0 , which would mean that the entire sample had 'right-wing' preferences, to 100 , meaning that the entire sample had 'left-wing' preferences. In order to shed more light on the evolution of the mood we marked election years with a vertical line.

Figure 1 about here 
Italians' policy preferences show some change over time. The trend, rather than being characterised by random abrupt shifts in the policy mood - large enough to be ascribed to external shocks that modify Italian public opinion as an aggregate - shows that changes in public opinion are essentially ‘changes at the margin' (Stimson; 1999). The Italian domestic policy mood confirms therefore a pattern of small but cumulative changes already found in previous studies in other democratic systems (Stimson 1999; Bartle, Dellepiane-Avellaneda and Stimson 2010; Bartle, Bosch and Orriols 2014).

Looking at Figure 1 we can identify three phases characterized by shifts in different directions: Italians' preferences moved to the right from 1981 through 1997; to the left between 1998 and 2008, and sharply back to the right from 2009. These trend changes correspond to clearly identifiable periods of recent Italian political history. The first period showing movements towards the right - coincides with the long sunset of the so-called First Republic (1981-1992) and the following political transition (1992-1996). These years were marked by significant international and domestic changes: the end of the Soviet Union and the Cold War, the corruption scandals and the consequent inquiries that brought about the collapse of the traditional Italian party system, and the enactment of a new electoral law, all of which most likely disoriented Italian citizens. The movement towards the right in Italian public opinion coincided with the transformation of the PCI into a social democratic party, the Democratic Party of the Left (Partito Democratico della Sinistra, PDS) and the birth a new centre-right party, Forza Italia (FI), led by the tycoon Silvio Berlusconi. The second period showing movement towards the left - almost coincides with the two longest legislatures of the so-called Second Republic (1996-2008): the first (1996-2001) characterised by four different and heterogeneous centre-left coalition governments, and the second one (2001-2006) dominated by the centre-right Berlusconi cabinets. After the initial stability of Italians' preferences, the graph shows a marked shift to the left in correspondence with the end of the 
second Berlusconi government. Finally, the last period - marked by a sharp movement to the right in the domestic policy mood - started in 2009 when the sovereign debt crisis that affected Southern European member states broke out and brought electoral gains for rightwing parties (Lindvall; 2014).

To check that our extracted measure indeed captures the left-right preferences of Italian citizens we have shown in Table A2 in the Appendix the highest factor loadings for those items that most contribute to the estimation of the policy mood. As can be seen, among these items we find typical controversial 'economic' issues easily interpretable in left-right terms but also extremely controversial 'cultural' issues. Among the former we find issues such as the government's responsibility to provide jobs, protect the lower classes and reduce income disparities. Among the latter we find issues related to abortion rights, immigration and religion. Overall, the estimated domestic policy mood explains more than 62 per cent of the variation in the assorted series included in the dataset. ${ }^{4}$

As a further check on the validity of our extracted measure in Figure 2 we compared the estimated domestic policy mood with a measure of the reported left-right positions of Italian citizens, estimated through the dyad ratio algorithm (see the dashed line). Even though the reported positions take higher values than policy preferences, the domestic policy mood series and the left-right self-placement series track each other quite well, at least until $2006 .{ }^{5}$ The product moment correlation for the two series over the $1981-2015$ period is $0.50(\mathrm{~N}=35$, $\mathrm{p}<0.01$ ). If we restrict the analysis to the 1981-2006 period the index of correlation between the two series reaches the impressive value of $0.79(\mathrm{~N}=26, \mathrm{p}<0.01)$.

Figure 2 about here 
In contrast, starting with the 2006 election Italians' policy preferences and their reported left-right positions show movements in opposite directions. While the domestic policy mood shifts to the left in 2005-08 and then to the right afterwards, left-right self-placement moves to the right between 2005 and 2010, turning back to the left thereafter. This finding is puzzling, since it shows a novel divergence between Italians' policy preferences and their selfrepresentation expressed by their location on the ideological left-right continuum. This is a divergence not observed for the previous 25 years. While we shall have to wait for new longitudinal data to assess the plausibility of such dis-anchorage - which would highlight the importance of social representation rather than of the policy content of the left-right continuum (see Corbetta, Cavazza and Roccato; 2009) - we can briefly speculate on its origin. Potential reasons for this divergence between Italians' reported left-right positions and their policy preferences can be found in the nature of the historical conjuncture. 2008 is considered as the year in which an international financial crisis affecting several European member states broke out, with European electorates initially moving towards the right (Lindvall, 2014). In 2011 the worsening of the sovereign debt crisis led the centre-right Berlusconi government to resign, making way for a technocratic executive led by the former EU commissioner, Mario Monti, with the precise aim of adopting austerity measures (Bellucci- 2014). While the crisis affected Italians' preferences over a range of policy issues, the left-right positions of Italian citizens did not move in the same direction. The share of citizens locating themselves on the left side of the spectrum increased after the experiences of the Berlusconi and Monti governments, and reached a new peak in 2013, even though the centre-left coalition failed to win a secure majority of votes in the legislative election. The divergence between the two movements might signal that when citizens face significant economic threats - such as increasing unemployment and a decline in the purchasing power of their salaries - the economic content of their ideological self-location becomes more salient 
and may lead them to discount other policy issues they consider temporarily less relevant (such as the family, the environment or abortion), or to change their opinions on other issues such as immigration. As a reaction to the consequences of the crisis, the EU's austerity policies and the increase in the flows of migrants, Italian citizens' attitudes have become more populist, anti-establishment and Euro-sceptic. ${ }^{6}$ Of course, we recognise that at this stage the previous discussion is inevitably ad hoc, and that an empirical test of the source of the divergent trend of policy preferences and people's reported left-right self-placement must await novel time-series data. What we have established is a measure of the Italian policy mood whose validity rests on a unidimensional solution of factor loadings and on a fairly strong correlation $(r=.50)$ with an external variable, i.e., people's reported left-right aggregate position. We move then, in the next section, to an analysis of the consequences of policy mood, focusing on the responsiveness of political actors to people's policy preferences.

\section{Policy Mood, Party Positions and Government Ideology}

Democratic theories claim that in representative democracies, the wishes or interests of the people should, to some degree, prevail in the decisions made by the government. In this section we investigate whether the ideological goals of governments and of the parties' proposals are related to citizens' policy preferences. The main questions we address are: Does public opinion react to shifting policy preferences of parties and governments? Do parties accommodate people's policy preferences in their electoral platforms? Do governments respond to changing popular preferences?

Existing studies argue that party competition in European political systems is usually limited to one or two policy dimensions (among others, Kitschelt 1994; Marks et al. 2006). Italy is no exception (Curini and Zucchini 2010). Although politics, theoretically, can be conceived as contest taking place in an infinite issue-space, there are many reasons that induce voters and parties to reduce this space to one or two dimensions. Given the complexity 
of politics, and their difficulty in processing multiple pieces of information, voters use ideology to reduce the multidimensionality of politics. Reducing the space of party competition to a very low number of dimensions helps parties to solve collective action problems in mobilising the electorate. Most models of party competition take into consideration only one dimension, which summarises different policy issues. This onedimensional space is represented by the traditional left-right spectrum (Downs 1957; Kitschelt 1994; Marks et al. 2006). ${ }^{7}$

Therefore, politics can be explained as a continuous competition between those demanding a more active role of the government in the economy as well as in other policy domains (the left-wing side), and those demanding less (the right-wing side). Citizens with extreme-left or extreme-right policy preferences will never be satisfied by the decisions taken by governments. By contrast, all those citizens somewhere in between these extreme positions have a motive to change preferences over time, and parties that alternate in government are induced to pay attention to them. According to such literature we can then advance two alternative conjectures about the relationship between policy mood and parties' and governments' ideology: the first is 'the balancing public', while the second is 'the responsive government'.

The first conjecture about the relationship between citizens', parties' and governments' preferences thus postulates that public opinion adjusts its preferences by demanding 'more' or 'less' policy activity in response to the different governments' policy outputs. Following Wlezien (1995)'s argumentation, citizens behave like a 'thermostat' demanding less or more of the policy they are receiving. After several years in which a government has implemented 'left-wing' policies, voters react by demanding a less active role for the government, and vice versa after a right-wing executive (Wlezien 1995; Soroka and Wlezien 2005). 
An alternative expectation can be formulated on the basis of Downs' model of twoparty competition in one-dimensional space (Downs 1957). To obtain control of government a political force should converge on the position of the median voter. Thus, shifts in public preferences over time necessarily imply that parties and then governments shift their preferences in the same direction (Pellegata 2016). Only shifts in a party's policy preferences large enough to include the median voter's preferences will allow it to govern. Therefore, the second conjecture assumes that governments react to movements of citizens' policy preferences by shifting their ideological preferences in the same direction.

In a process of continuous mutual adjustment between citizens' and governments' policy preferences, to determine systematically whether the public changes its preferences as a reaction to governments' shifts, or vice versa, is not an easy task. Likewise, although on the basis of both these expectations preference shifts are entirely endogenous to the relationship between voters and governments, an appropriate empirical test should also take into account exogenous factors, such as economic conditions, government popularity, corruption scandals, etc. -We leave these empirical controls to a subsequent study, and discuss here some exploratory analyses that describe the links between citizens', parties' and governments' preferences.

Parties' policy positions are computed from the Comparative Manifesto Project data (CMP, Budge et al. 2001; Klingemann et al. 2006). The position of the left-wing parties or coalitions is measured through the average left-right position of all parties weighted by their seat shares in the Chamber of Deputies. We have rescaled the original CMP metric - where 100 represents extreme left and +100 represents extreme right - onto a 'policy-mood' scale where 0 represents the extreme right and +100 represents the extreme left. In order to measure governments' policy positions we rely on a different data source. 
Governments' positions on the left-right scale have been estimated using the Italian Legislative Speech Dataset (ILSD, Curini and Martelli 2009). Governments' preferences are inferred from a content analysis of the investiture speeches made by prime ministers to Parliament. These estimations are based on the same methodology and the same policy categories adopted for the CMP project. In addition, the original ILSD scale, which runs from -100 at the extreme left and +100 at the extreme right, was transformed in order to obtain the same metric of policy mood, where the latter runs from 0 (extreme right) to 100 (extreme left).

We preferred to use ILSD rather than CMP data to estimate the position of governments for two main reasons. The first is that the ILSD dataset gives us a more realistic estimation of the position of different governments, - than CMP data which only providing provide an estimation of the positions of parties obtained from their electoral manifestos. Starting from these estimations scholars should compute governments' preferences. ILSD data instead infer both parties' and governments' preferences. The latter are directly estimated from the prime ministers' investiture speeches, which are the result of post-electoral bargaining among coalition partners. The second reason is that CMP data captures parties' preferences only before the elections. This strategy does not allow scholars to estimate the positions of those governments that take office between elections, as happens particularly frequently in Italy. ILSD data instead enable one directly to estimate the preferences of all the governments that succeeded one another in the Italian Republic.

Let us inspect first some descriptive data, before moving then to structured explanatory models. To what extent do parties' ideological positions reflect citizens' policy preferences? Or in other words: do voters react as a thermostat? Figure 3 presents a bar chart which, for each pair of elections over the 1983-2013 period, plots changes in domestic policy mood (white bars) and changes in the left-right position of left-wing parties (hard grey bars) ${ }^{8}$. 
In six out of eight pairs of elections analysed we detect a systematic congruence between the movement of citizens' policy preferences and movement of the proposals of left-wing parties or coalitions, based on their election manifestoes. So parties and electorates show a slight tendency to move in tandem. In 1987, 2001 and 2006 both the policy mood and left-wing parties' ideological positions shifted to the left compared to previous elections, while in 1992 , 1994 and 1996 the two measures moved to the right. Finally, only in the last two elections in 2008 and 2013 - do changes in policy mood fail to track the changes in the ideological positions of the centre-left coalition. Overall, the evidence so far analysed would support the party-responsiveness rather than the balancing-public hypothesis.

Figure 3 about here

To probe further the balancing hypothesis, we can investigate whether it is possible to detect a change in the Italian policy mood between the start and the end of the tenure of governments of different complexions. Figure 4 reports changes in the domestic policy mood under different governments. As before, positive values indicate movement to the left, while negative values indicate movement to the right. More precisely, all the executives with the same partisan composition and/or the same ideological 'label' are considered as single governments. For instance, between 1983 and 1991 six different governments held office but, referred to as ' $i$ governi del pentapartito', ${ }^{9}$ their partisan composition remained the same. In the same way, between 1996 and 2001 four governments and three prime ministers succeeded one another. These governments were partially different in terms of partisan composition but they could all be subsumed under the 'centre-left' ideological label.

Figure 4 provides little evidence to support the thermostat idea. Only in 2006, following the tenure of the second and third Berlusconi governments of the centre right beginning in 
2001, do we detect a significant movement to the left in the public's policy preferences. At the end of the other ideologically-defined executives of the Second Republic (the centre right in 1994-1995 and 2008-2011 and the centre left in 1996-2001 and 2006-2008) we do not identify shifts in the policy mood in directions opposed to the governments' ideological positions. It is of course more difficult to test the thermostat hypothesis in the cases of the remaining governments given their uncertain ideological positions. At the end of the two technocratic governments (Dini 1995-1996 and Monti 2011-2013) we detect a movement to the right in citizens' policy preferences, while we would have expected a movement to the left considering the financial austerity measures implemented by them. Similarly, we would have expected a movement to the left, instead of to the right after the two most recent governments. The Letta government (2013-2014) was a 'grand coalition' consisting of the largest centre-left party, the Democratic Party (Partito Democratico, PD), the largest centre-right party (the Popolo della Liberta, now renamed Forza Italia) and several small political forces located in the ideological centre. The Renzi government was led by the PD, but in coalition with several small centre and centre-right parties.

Figure 4 about here

What happens if we shift the focus from parties' preferences - expressed by the parties' programmes before the elections - to the preferences of governments, based on the prime ministers' speeches, which represent the actual policy commitments of governments installed after the elections? Figure 5 reports the change in domestic policy mood (light grey bars) and the change in the left-right position of governments with respect to the previous government with a different partisan composition and/or a different ideological label (hard grey bars). We observe a congruence between policy mood and governments' left-right preferences in five 
out of ten pairs of governments analysed. This ideological congruence is present in the last government of the so called First Republic (Andreotti VII in 1991), together with the Berlusconi II government (2001) and the Prodi II cabinet (2006) and the two more recent executives (Letta in 2013 and Renzi in 2014). In the other five pairs of governments analysed, policy mood and governments' preferences move in opposite directions. However, it is not correct to infer that such instances show public opinion reacting in a thermostatic manner since a movement to the right of a new government - such as the first Berlusconi government with respect to the previous Ciampi government in 1994, or the fourth Berlusconi government with respect to the second Prodi government in 2008 - corresponds to a synchronous shift of public opinion to the left. According to the thermostatic model we should have observed a shift in the opposite direction after the change in government. At best, then, these cases are instances of faltering responsiveness.

Figure 5 about here

Before reaching such a conclusion we must however acknowledge that the evidence so far shown, albeit illustrative, is not able to provide an accurate or conclusive answer to the public opinion-parties nexus. We can improve over such static contrasts - that is the paired comparisons between outgoing governments during an electoral term that we have so far considered - by introducing a dynamic component to the analysis. We do so via a more refined modelling of the political leanings of executives and their duration in office. Moreover, we enlarge the number of our observations by also including the governments that have taken office without any change of political composition, thus taking into account the short duration of governments which characterises the Italian political system. Such frequent changes of government - resulting from disagreement among the coalition partners - entailed 
differences in policy pledges which might have reflected not only the need to accommodate different parties' interests but perhaps also a change in the mood of public opinion. Such inclusion enlarges the sample to 20 governments for a total of 35 observations.

We measure the political leaning and duration of governments using a variable (Incumbency) that assumes a value of 1 for the first year of a centre-left government, increasing by 1 for each year of its tenure; and that assumes a value of -1 for the first year of a centre-right government and decreases by $1(-2,-3,-4$, etc.) each year thereafter, while nonpartisan governments are coded 0 .

Let us start with the 'balancing public' conjecture. Table 1 reports the findings of a regression of mood on incumbency, both for the shorter time series limited to election years (Model 1, column 1) and for the extended one covering all governments (model 2, column 2). Model 1 provides an estimate of data graphed in Figure 4 but improves over the measurement of government tenure, as previously described. The coefficient for Moodof Incumbency, although not statistically significant at conventional levels due to the small $\mathrm{N}$, is negative $(\mathrm{b}=$ -0.36). This means that the longer a centre-left government rules the more the public mood shifts to the right. Model 2 - considering all government policy pledges - confirms such a result. The Incumbency coefficient $(b=-0.45$; statistically significant) shows that each year of tenure of a leftist/rightist government shifts the popular mood to the right/left by half a percentage point. These estimates provide some support to the balancing-public conjecture, although they show merely a tendency rather that a strong causal impact, as the variance explained by the models is modest (respectively $15 \%$ and $23 \%$ ).

Table 1 about here 
Having ascertained that the Italian public to an extent adjusts its policy preferences according to the policy supply, we turn to the second conjecture, that of the responsiveness of policy to public opinion. Table 2 reports estimates of a model which regresses (change in) the policy positions of pre-electoral parties' manifestoes and governments' policies on (the change in) the public mood, controlling for parties'/governments' previous (lagged) positions. Model 1 shows that (centre-left) parties' policy positions do respond to the public mood. On average, a one-percent change in mood towards the left elicits an almost equal movement $(b=$ 0.93) of parties' positions to the left. Although the coefficient only borders statistical significance $(\mathrm{t}=1.63 ; \mathrm{p}=0.154)$, such great elasticity in the responsiveness of parties to public opinion appears confirmed when moving to the longer government time series (Model 2): the regression coefficient, statistically significant $(t=1.71 ; \mathrm{p}=0.09)$, shows that a unit change in the popular mood to the left/right is mirrored by a 0.88 movement of government policy in the same direction. The model's fit has improved (respectively 54\% and 40\%) and signals that the responsiveness of both parties and especially government to the public's preferences is - to the authors' surprise - a feature of Italian democracy, not distant from what comparable research has uncovered.

Our analysis has investigated the two sides of the representation cycle: the findings show an adaptive public responding to the policy supply, adjusting their policy preferences over time and moving in the opposite direction vis-a-vis the status quo. At the same time, parties and governments appear to respond to such popular preferences. Data limitations prevent a simultaneous estimation of these two flows, something that would have made it possible to gauge their interplay in greater detail. Such limited analysis has therefore been constrained to assess each path independently. Results available so far seem to suggest although neither conjecture has been rejected - that the balancing public appears weaker than policy responsiveness. This leaves open for further research the origin of the public's policy 
preferences and its evolution over time, in response to exogenous factors, such as economic conditions, government popularity, corruption scandals and above all policy implementation. Finally, a not irrelevant finding of this research concerns the need to fine-tune the analysis. As our descriptive examination above has shown, comparing government policy positions and public preferences between electoral cycles hides many nuances that meticulous yearly and cabinet-by-cabinet data can uncover.

Table 2 about here

\section{So What? Policy Mood and Electoral Outcomes}

It is a plausible hypothesis that public policy preferences influence voters' political choices at elections, although in the past, research was seldom able to confirm it. Actually, research into political behaviour has recently moved away from reliance on social cleavages and partisanship as key explanatory factors, towards choice models of voting behaviour (Clarke et. al.; 2001), focusing on medium-term factors like the citizens' evaluations of the economy, of leaders and their policy preferences (Lewis-Beck 1988; Bellucci 2002; 2007). Nevertheless, scholars are not unanimous regarding the resilience of partisanship, the reasons for its decline or its (supposedly lesser) influence on citizens' voting choices (Dalton and Wattenberg 2002; Bartle and Bellucci 2009). Our contribution to the debate, in this paper, is a first attempt to investigate, relying on aggregate data, the impact of policy mood on Italians' voting choices. The key question we try to answer is: Are changes in domestic policy mood reflected in people's voting choices? As a caveat we need to recognise our inability, at this stage of the analysis, to ascertain the causal connection between voting and policy mood - i.e. whether voting choice is (as commonly assumed) the source of policy preference or the consequence (as choice theory proposes) - and admit that endogeneity might affect our findings. 
Figure 6 offers a first, albeit inconclusive, answer to the previous questions. It shows, for the eight pairs of elections that took place between 1983 and 2013, changes in domestic policy mood (white bars) and changes in the vote shares of left-wing parties for the Chamber of Deputies (dark grey bars). Positive values indicate a shift to the left in the policy mood and an increase in the vote share obtained by left-wing parties, all measured as first differences from previous elections. ${ }^{10}$

Figure 6 about here

In four out of the eight pairs of elections included in Figure 6 we detect a perfect correspondence between the direction of the change in the domestic policy mood and the vote share obtained by these parties. In 1992 and 2013, Italians' policy preferences shifted to the right and the vote share obtained by left-wing parties decreased. In 2001 and 2006 findings are again congruent: the mood shifted to the left and the vote share obtained by left-wing parties increased. In the remaining elections $(1987,1994,1996,2008)$ vote changes show no correlation with the changes in policy mood. ${ }^{11}$

These findings are puzzling, since they lend support to contradictory hypotheses on the causal relationship between policy mood and voting. What could account for such differences? Many interpretations are obviously possible, but here we focus on one institutional explanation. These elections differ as to the duration of legislatures. Only those elections held at the completion of the institutional term (5 years: 1992, 2001, 2006, 2013) display a systematic association between a shift to the left (right) in the Italian domestic policy mood (compared to the level at the beginning of the legislature) and an increase (decrease) in left-wing parties' vote shares. When legislatures lasted for the whole of their natural terms and were characterised by the presence of governments of similar ideological 
positions, voters seemed more inclined to base their voting choices on short- and mediumterm factors, such as policy preferences. In contrast, in shorter and fragmented legislatures which include the two legislatures of the transition to the Second Republic (1992-1994 and 1994-1996) - the electorate may have been bewildered and might have chosen to rely on the partisanship shortcut to make their voting choices.

We test the previous supposition with a regression model where change in left-wing (and after 1992 centre-left) parties' shares of the vote are regressed on changes in the popular policy mood, controlling for previous vote shares. Model 1 in Table 3 shows a positive relationship (the Mood coefficient $b=0.86$ ), where a one percentage shift to the left in Mood brings about a positive change of 0.86 of a percentage point in vote share. This impact is short of statistical significance, due both to the short time series and to the likely impact of elections called early. The introduction of an interaction of Mood with a variable tapping full legislative term significantly alters the findings (Model 2). The coefficient of Mood (which refers now to elections called early) is negatively signed and statistically insignificant, thus indicating great uncertainty as to its impact on the vote, while its interaction (which refers to completed legislative terms) is positively signed and statistically significant. It shows a great impact of policy mood on voting choice: a one percentage point change in mood brings about gains in the leftist vote of over two percentage points. Albeit only preliminary, these findings suggest that further research is warranted and that the model specification should be improved by introducing other important factors affecting election outcomes (e.g. party competence, leadership assessment and the costs of ruling).

Table 3 about here

\section{Conclusion}


This study has investigated the relationship between the policy preferences of citizens, parties and governments, and electoral behaviour in Italy between 1981 and 2015, a period that encompasses the end of the so called First Republic, the legislatures of the so called Second Republic and the recent post-crisis years. We have proposed a measure of policy mood, i.e. public policy-preferences estimated from responses to survey questions on controversial domestic policy issues through the dyad ratio algorithm, which allows us to compare changes in public preferences over time. Its trend shows incremental changes. We have detected three different phases: a shift to the right in the policy mood in correspondence with the end of the First Republic and the transition toward the Second Republic (1981-1997); a shift to the left during the main legislatures of the Second Republic, between 2005 and 2008; and finally a sharp turn to the right after the outbreak of the Great Recession in 2008-09.

When linking policy mood to the political system, our expectations were rather bleak, but the positive findings surprised us. There are several caveats concerning the correct functioning of Italy's democratic institutions. The never-ending reform of the electoral system, the competition structured around two broad, heterogeneous and volatile coalitions, the high levels of party switching, the recourse to technocratic non-partisan executives and the recent rise of electoral stecess-consent of an anti-establishment and populist party (M5S) all represent strong challenges to democratic accountability and the responsiveness of governments' policies to citizens' preferences.

Nevertheless, our results shed rather positive light on the representationresponsiveness process in Italy. The main findings show that in the Second Republic, especially in those legislatures that lasted for their natural terms, there is quite a systematic correspondence between public-preference shifts and election results. Moreover, with the exception of the last two legislatures, we have detected a congruence between shifts in policy 
mood and shifts in the ideology of left-wing parties. And we uncovered an important congruence between citizens' and governments' preferences.

These results allow preliminary but rather relevant conclusions. First of all, for almost all of the period covered by the analysis there is a systematic congruence between (left-wing) parties' ideological positions and policy preferences. In addition, governments' positions tend to converge towards citizens' preferences. Second, there is a strong association between citizens' voting choices and their policy preferences. Medium- and short-term factors thus play a significant role in driving citizens' electoral behaviour. The majoritarian reforms and the bi-polar competition of recent years have prompted voters to take into consideration their policy preferences in making their voting choices.

The analysis to an extent sustains the idea of a public opinion acting as a thermostat to balance the governments' policy goals and, likewise, it provides somewhat stronger evidence for the argument that parties and governments adapt their preferences according to changes in public opinion. Overall it shows that a working democracy is sustained by iterative interactions between public opinion and political representatives.

\footnotetext{
${ }^{1}$ Unfortunately, the data before 1981 are very thin. We found questions on Europe in Eurobarometer surveys from 1973 and questions on citizens' left-right self-placement from 1968. However, questions on more specific domestic policy issues are very scarce in the most important available data sources. Therefore, we decided to discount all questions asked before 1981 .

${ }^{2}$ Following Stimson (1999), Bartle, Dellepiane-Avellaneda and Stimson (2010) and Bartle, Bosch and Orriols (2014), we have computed 'leftist' preferences as a proportion of total preferences, but we could have calculated 'rightist' preferences as a proportion of the total.

${ }^{3}$ For a detailed explanation of the dyad ratio algorithm see Stims on (1999: 133-137).

${ }^{4}$ We have also estimated a second policy dimension given the structure of our data. However, the second extracted dimension accounts for only 5.7 per cent of the total variance. This result clearly indicates the presence of only one underlying policy dimension given the preferences of Italian citizens.
} 
${ }_{5}^{5}$ Bartle et al. (2011) found a similar positive relationship when comparing the policy mood in the post-war United Kingdom with citizens' reported left-right preferences.

${ }^{6}$ The shift to the right in the policy preferences of Italian citizens has also been observed by Baldassarri (2013) who conducted an analysis using the 2013 ITANES post-national election survey.

${ }^{7}$ Kitschelt (1994) refers to this dimension using the term left-libertarian/right-authoritarian, which summarises, first and foremost, the economic left-right dimension and a second, more context-specific, dimension that captures several non-economic issues such as the environment, lifestyle, and community, which scholars usually label GAL/TAN.

8 During the First Republic (the 1983, 1987 and 1992 elections) we considered as left-wing parties the Italian Communist Party (Partito Comunista Italiano, PCI) and Proletarian Democracy (Democrazia Proletaria, DP). These parties were chosen because they clearly represented left-wing alternatives to the main government party, the Christian Democrats (Democrazia Cristiana, DC). Parties such as the Italian Socialist Party (Partito Socialista Italiano, PSI) and the Italian Social Democratic Party (Partito Socialista Democratico Italiano, PSDI) are not included among the parties of the left because during the 1970 s and, above all the 1980 s, they participated in several coalition governments with the DC. Starting with 1994 we identified as left-wing all those parties that formed the centre-left coalitions that contested the various elections. We repeated the same analysis taking into account right-wing parties. Results obtained were the same as the ones presented so we do not reproduce them in the article. They can be requested from the authors.

9 The 'pentapartito' was a government alliance involving five parties (the DC, the PSI, the Italian Republican Party (Partito Repubblicano Italiano, PRI), the PSDI and the Italian Liberal Party (Partito Liberale Italiano, PLI)). Among the six executives that held office between 1983 and 1991 Fanfani VI was a single-party government staffed by the DC. However, given that it was a so-called 'governo balneare', which lasted for only three months before the 1987 general election, we included it among the other executives reflecting the 'pentapartito' formula.

${ }^{10}$ See Footnote 8 for the classification of left-wing parties. We repeated the analysis taking into account the electoral performance of right-wing parties with similar results. They are available from the authors.

${ }^{11}$ This result is in line with Erikson et al. (2002) who, even if relying on an abundance of data, did not find any significant relationship between policy mood and macro-partisanship in the US. 


\section{References}

Adams, James. 2012. Causes and Electoral Consequences of Party Policy Shifts in Multiparty Elections: Theoretical Results and Empirical Evidence". Annual Review of Political science. 15: 401-419.

Baldassarri, Delia. 2007. "Sinistra e Destra: La Dimensione Ideologica tra Prima e Seconda Repubblica.” In Gli Italiani e la Politica, edited by Marco Maraffi, 105-130. Bologna: Il Mulino.

Baldassarri, Delia. 2013. “Sinistra e Destra: Un’Italia di Moderati e Conservatori.” In Voto Amaro: Disincanto e Crisi Economica nelle Elezioni del 2013, edited by ITANES, 133-146. Bologna: Il Mulino.

Bartle, John and Paolo Bellucci. Eds. 2009. Political Parties and Partisanship. Social Identity and Individual Attitudes. London: Routledge.

Bartle, John, Agusti Bosch and Lluis Orriols. 2014. "The Spanish Policy Mood, 1978-2012.” Unpublished work.

Bartle, John, Sebastian Dellepiane-Avellaneda, and James Stimson. 2010. “The Moving Centre: Preferences for Government Activity in Britain, 1950-2005.” British Journal of Political Science 41: 259-285. doi: 10.1017/S0007123410000463.

Bellucci, Paolo. 2002. "From Class Voting to Economic Voting: Patterns of Individualization of Electoral Behavior in Italy, 1972-1996.” In The Changing Economic Voter, edited by Hand Dorussen and Mark Taylor, 261-283. London: Routledge.

Bellucci, Paolo. 2007. “Changing Models of Electoral Choice.” Modern Italy 12(1): 55-72. doi: 10.1080/13532940601134841.

Bellucci, Paolo. 2014. "The Political Consequences of Blame Attribution for the Economic Crisis in the 2013 Italian National Election.” Journal of Elections, Public Opinion and Parties 24(2): 243-263. 
Bellucci, Paolo and Nicolò Conti (Eds.). 2012. Gli italiani e l'Europa. Opinione pubblica, élite politiche e media. Roma: Carocci.

Benoit, Kenneth and Michael Laver. 2006. Party Policy in Modern Democracies. London: Routledge.

Box-Steffensmeier, Janet M. and Suzanna De Boef. 2001. "Macro-Partisanship and MacroIdeology in the Sophisticated Electorate.” Journal of Politics 63(1): 232-248. doi: 10.1111/0022-3816.00066.

Budge, Ian, Hans Dieter Knlingemann, Andrea Volkens, Judith Bara and Eric Tanenbaum. 2001. Mapping Policy Preferences: Estimates for Parties, Electors and Governments 1945-1998. Oxford: Oxford University Press.

Campbell, Andrea L., 2012. "Policy Makes Mass Politics". Annual Review of Political Science. $15: 333-51$.

Clarke, Harold D., David Sanders, Marianne C. Stewart, and Paul Whiteley. 2004. Political Choice in Britain. Oxford: Oxford University Press.

Corbetta, Piergiorgio, Nicoletta Cavazza, Michele Roccato. 2009. "Between Ideology and Social Representation: Four Theses Plus (a New) One On the Relevance and the Meaning of the Political Left and Right.” European Journal of Political research 48: 622-641. doi: 10.1111/j.1475-6765.2009.00845.x.

Curini, Luigi and Paolo Martelli. 2009. I partiti nella Prima Repubblica. Maggioranze e governi dalla Costituente a Tangentopoli. Roma: Carocci.

Curini, Luigi and Francesco Zucchini. 2010. "Testing the Law Making Theories in a Parliamentary Democracy: A Roll Call Analysis of the Italian Chamber of Deputies (1988-2008)." In Reform Processes and Policy Change: Veto Players and Decisionmaking in Modern Democracies, edited by Thomas König, George Tsebelis \& Marc Debus, 189-2011. New York: Springer. 
Dalton, Russel and Martin P. Wattenberg. 2002. Parties without Partisans: Political Change in Advanced Industrial Democracies. Oxford: Oxford University Press.

Delli Carpini, Michael X. and Scott Keeter. 1989. What Americans Know about Politics and Why It Matters. New Haven: Yale University Press.

Downs, Anthony. 1957. An Economic Theory of Democracy. New York: Harper and Row.

Erikson, Robert S., Michael B. MacKuen and James A. Stimson. 2002. The Macro Polity. Cambridge: Cambridge University Press.

Hobolt, Sara B. and Robert Klemmemsen. 2005. "Responsive Government? Public Opinion and Government Policy Preferences in Britain and Denmark”. Political Studies. Vol. 53: $379-402$.

Kitschelt, Herbert. 1994. The Transformation of European Social Democracy. New York: Cambridge University Press.

Klingemann, Hans Dieter, Andrea Volkens, Judith Bara, Ian Budge and Michaell P. MacDonald. 2006. Mapping Policy Preferences: Estimates for Parties, Electors, and Governments in Eastern Europe, European Union and OECD 1990-2003. Oxford: Oxford University Press.

Laver, Michael and William B. Hunt. 1992. Policy and Party Competition. London: Routledge.

Lewis-Beck, Michael. 1988. Economics and Elections: The Major Western Democracies. Ann Arbor: University of Michigan Press.

Lindvall, Johannes. 2014. “The Electoral Consequences of Two Great Crises.” European Journal of Political Research 53(4): 747-765. doi: 10.1111/1475-6765.12055.

Marks, Gary, Liesbet Hooghe, Moira Nelson and Erica Edwards. 2006. "Party Competition and European Integration in East and West. Different Structure, Same Causality.” Comparative Political Studies 39(3):155-75. doi: 10.1177/0010414005281932. 
Pellegata, Alessandro. 2016. “Assessing the Complex Relationship between Government Alternation and Ideological Congruence.” International Political Science Review 37(1): 51-65. doi: 0.1177/0192512114539435.

Powell, G. Bingham. 2000. Elections as Instruments of Democracy: Majoritarian and Proportional Visions. New Haven: Yale University Press.

Scarbrough, Elinor. 1984. Political ideology and Voting Behaviour: An Exploratory Study. Oxford: Clarendon Press.

Soroka, Stuart N. and Christopher Wlezien. 2005. “Opinion-Policy Dynamics: Public Preferences and Public Expenditure in the United Kingdom." British Journal of Political Science 35(4): 665-689. doi: 10.1017/S0007123405000347.

Stimson, James A. 1999. Public Opinion in America. Moods, Cycles and Swings. Boulder: Westwiew Press.

Stimson, James A. 2004. Tides of Consent. How Public Opinion Shapes American Politics. Cambridge: Cambridge University Press.

Stimson, James A., Michael B. Mackuen and Robert S. Erikson. 1995. "Dynamic Representation.” American Political Science Review 89(3): 543-565. doi: $10.2307 / 2082973$

Stimson, James A., Cyrille Thiébaut and Vincent Tiberj. 2012. “The Evolution of Policy Attitudes in France.” European Union Politics 13(2): 293-316. doi: $10.1177 / 1465116512436703$.

Wlezien, Christopher. 1995. "The Public as Thermostat: Dynamics of Preferences for Spending.” American Journal of Political Science 39(4): 981-1000. doi: $10.2307 / 2111666$.

Wlezien, Christopher. 2004. "Patterns of Representation: Dynamics of Public Preferences and Policy ." The Journal of Politics 66(1): 1-24. doi: 10.1046/j.1468-2508.2004.00139.x. 
Table 1. The Impact of Incumbency (Election Years and Government Pledges) on the Public Mood (OLS - Standard Error in parentheses)

\begin{tabular}{lcc}
\hline Variable & $\begin{array}{c}\text { Model 1 } \\
\text { Election Years }\end{array}$ & $\begin{array}{c}\text { Model 2 } \\
\text { Government Pledges }\end{array}$ \\
\hline Intercept & $58.7(1.13)^{* * *}$ & $57.6(.58)^{* * * *}$ \\
Incumbency & $-0.36(.23)$ & $-0.45(.13)^{* * *}$ \\
$\mathrm{~N}$ & 9 & 35 \\
Adj. $\mathrm{R}^{2}$ & 0.15 & 0.23 \\
\hline
\end{tabular}

$* * * \mathrm{p}<0.01$ (two tailed test)

Note: Dependent variable is the Policy Mood; Incumbency: Centre-Left government tenure = 1, 2, $3 \ldots \mathrm{N}$; Centre-Right government tenure $=-1,-2,-3,-\mathrm{N}$; non-partisan government $=0$ 
Table 2. Responsiveness of Pre-Electoral Centre Left Parties' Manifestoes and Government

Pledges to the Public's Policy Mood (OLS - Standard Error in parenthesis)

\begin{tabular}{lcc}
\hline Variable & $\begin{array}{c}\text { Model 1 } \\
\text { Pre-Electoral } \\
\text { Government Parties } \\
\text { Manifestoes }\end{array}$ & $\begin{array}{c}\text { Model 2 } \\
\text { Government } \\
\text { Pledges }\end{array}$ \\
\hline Intercept & $58.7(1.13)^{* * *}$ & $34.6(7.39)^{* * *}$ \\
Delta Mood & $0.93(.57)+$ & $0.88(.52)^{*}$ \\
Lagged Centre Left & $-1.11(.33)^{* * *}$ & $-0.79(.17)^{* * *}$ \\
Parties/Government Position & 9 & 34 \\
N & 0.54 & 0.40 \\
Adj. $\mathrm{R}^{2}$ & & \\
\hline
\end{tabular}

$* * * \mathrm{p}<0.01: * \mathrm{p}<0.10 ;+\mathrm{p}=0.15$ (two-tailed test)

Note: Dependent variable is the change (first differences) in the policy positions of Centre Left Parties' Manifestoes since the previous election (Col. 1), and change in Government Pledges since the previous government (Col.2); Delta Mood is the change (first differences) in Public Mood since the previous election year (Col. 1)/previous government (Col. 2) 
Table 3. The Electoral Consequences of the Public Mood for Centre-Left Parties

\begin{tabular}{lcc}
\hline Variable & $\begin{array}{c}\text { Model 1 } \\
\text { (Centre) Left } \\
\text { parties' vote share }\end{array}$ & $\begin{array}{c}\text { Model 2 } \\
\text { (Centre) Left } \\
\text { parties' vote share }\end{array}$ \\
\hline Constant & $23.44(12.77)^{* *}$ & $1.16(2.80)$ \\
Delta Mood & $0.86(.75)$ & $-0.85(1.12)$ \\
Lagged Centre Left Vote (\%) & $-0.65(.35)^{* *}$ & \\
Full Legislative Term & & $0.55(.56)$ \\
Full Legislative Term * Delta Mood & 9 & $2.42(1.47)^{*}$ \\
N & 0.19 & 9 \\
Adj. $\mathrm{R}^{2}$ & & 0.13 \\
\hline
\end{tabular}

$* * \mathrm{p}<0.05: * \mathrm{p}<0.10$ (one-tailed test)

Note: Dependent variable is the change in the Centre Left Parties' vote share (first differences) since the previous election; Delta Mood is the change (first differences) in the Public Mood since the previous election; Full Legislative Term is a dummy variable indexing completed Legislation; Full Legislative Term * Delta Mood interacts Delta Mood with election years of completed legislature. 


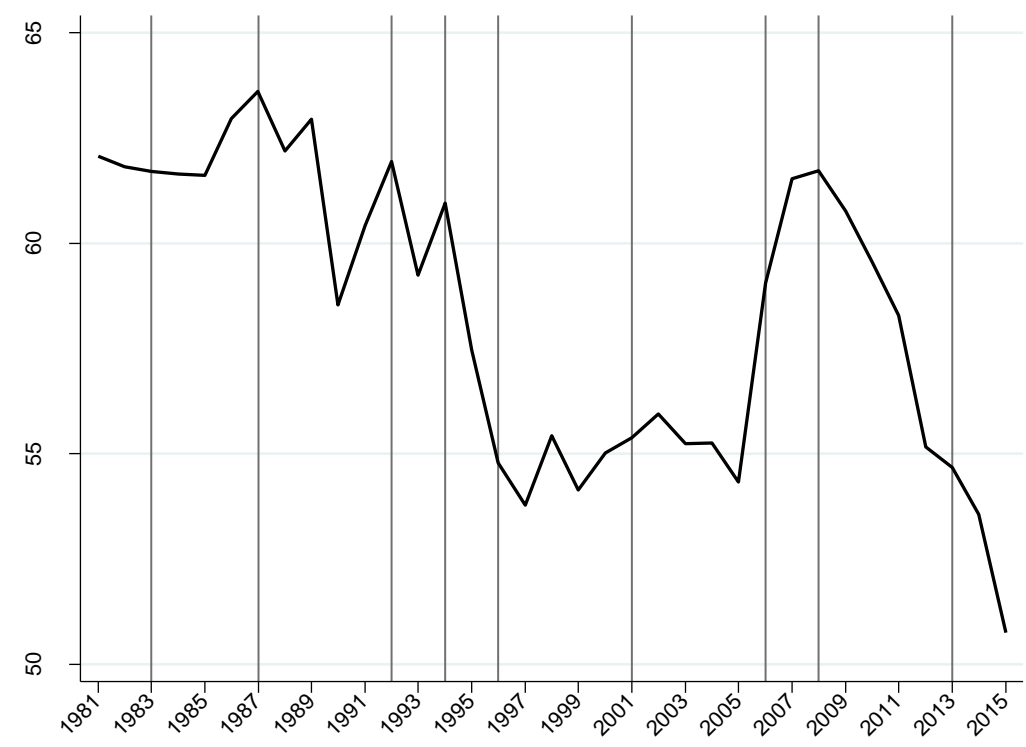

Figure 1. The Italian domestic policy mood (1981-2015) with election years highlighted.

Note: Vertical lines mark election years.

Source: See Table A1 in the Appendix.

35 


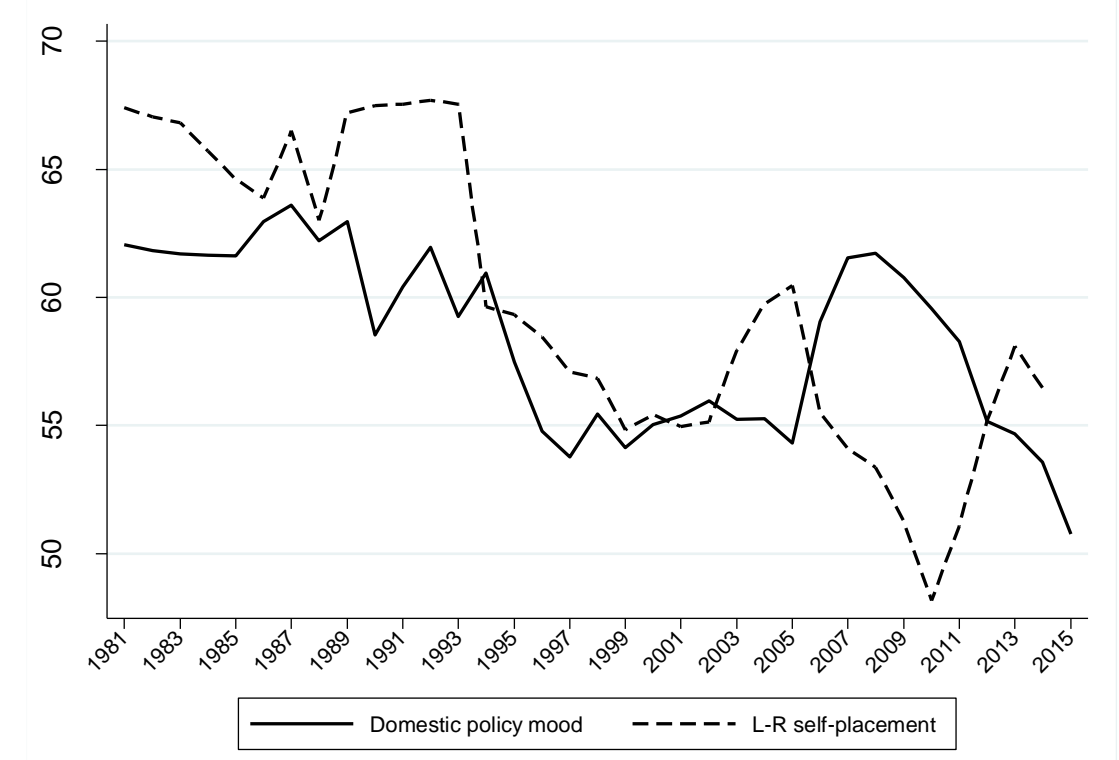

Figure 2. The Italian domestic policy mood.

Source: See Table A1 in the Appendix.

Figure 2. The Italian domestic policy mood.

Souree: See Table $\mathrm{Al}$ in the Appendix. 


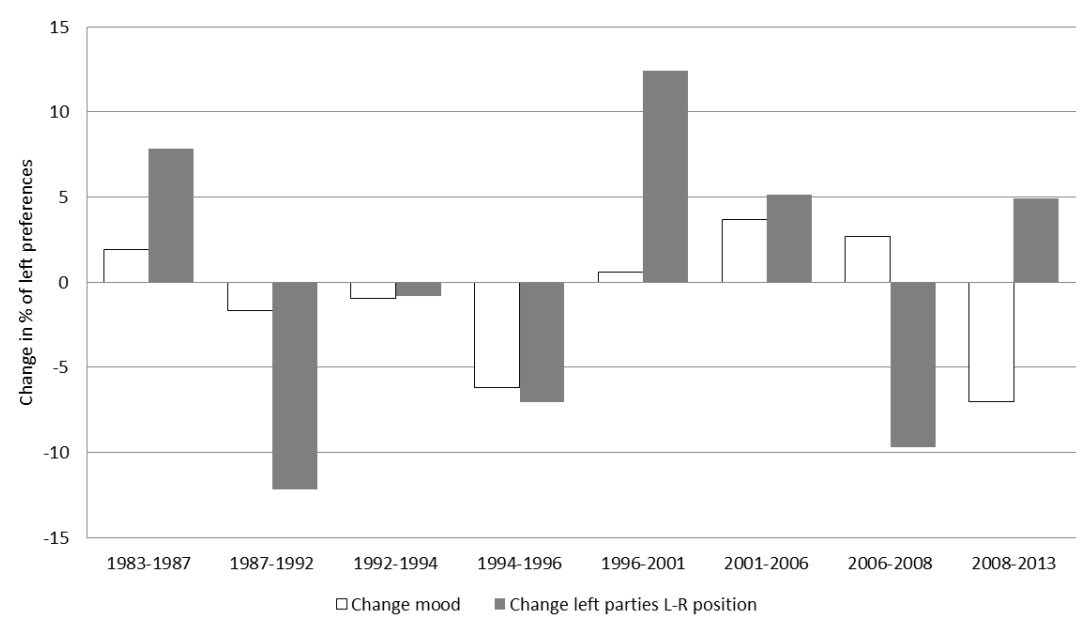

Figure 3. Relationship between mood and left-wing parties' positions in left-right space for pairs of elections (1983-2015). 


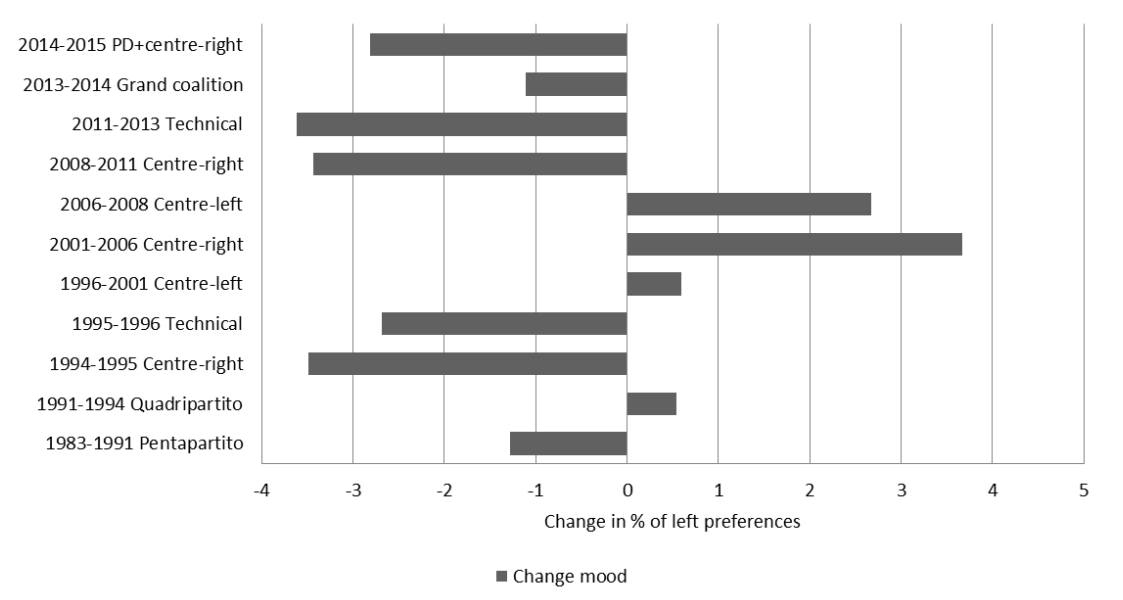

Figure 4. Change in the domestic policy mood between the beginning and the end of each government (1983-2015).

Source: Italian policy mood dataset. 


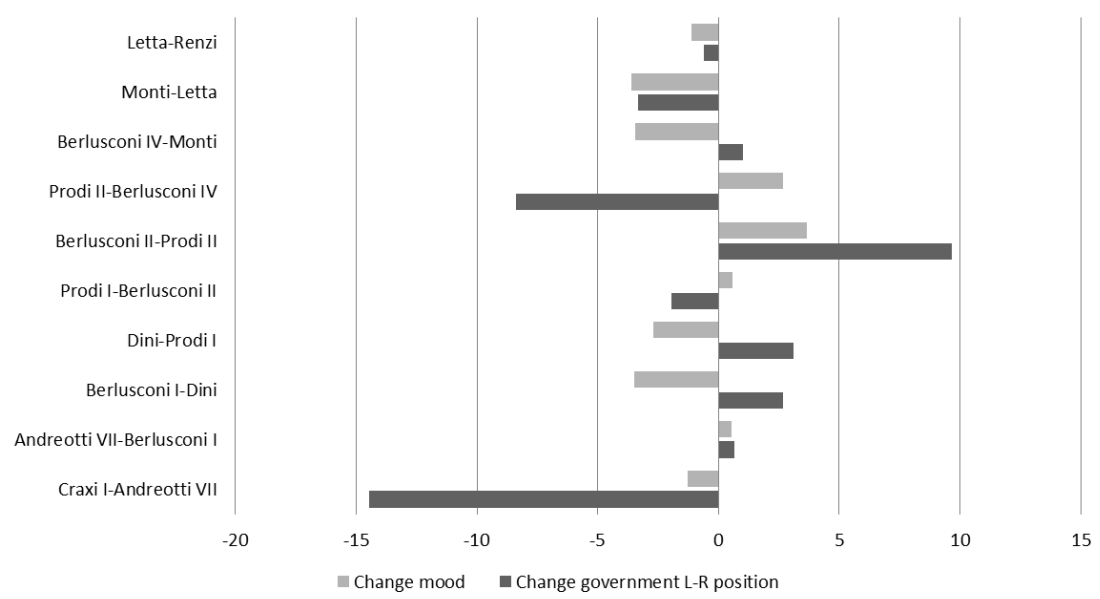

Figure 5. Change in the domestic policy mood and governments' left-right positions for each pair of governments (1983-2015).

Source: Italian policy mood dataset; Italian Legislative Speeches Dataset (Curini and Martelli 2009) 


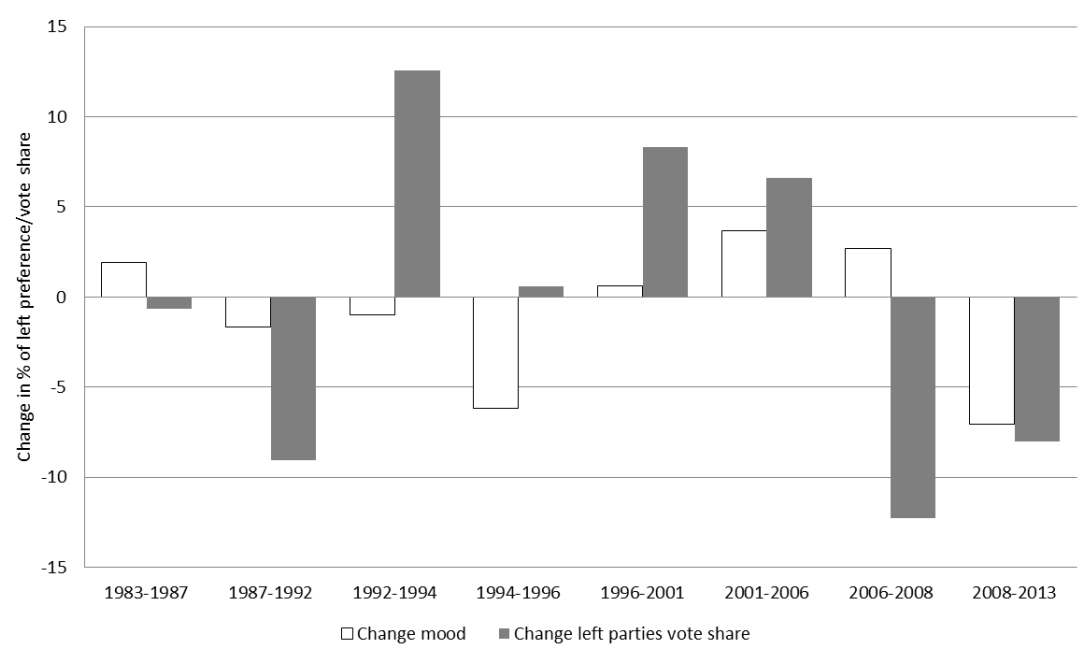

Figure 6. Relationship between mood and left-wing parties' vote share for pairs of elections (1983-2015).

Source: Italian policy mood dataset; ParlGov database. 


\section{Appendix}

Table A1. Data sources.

\begin{tabular}{lcccc}
\hline & \multicolumn{2}{c}{ Full dataset } & \multicolumn{2}{c}{ Domestic policy mood } \\
\cline { 2 - 5 } House & $\begin{array}{c}\text { Num. } \\
\text { Questions (\%) }\end{array}$ & $\begin{array}{c}\text { Num. } \\
\text { Admin. (\%) }\end{array}$ & $\begin{array}{c}\text { Num. } \\
\text { Questions (\%) }\end{array}$ & $\begin{array}{c}\text { Num. } \\
\text { Admin. (\%) }\end{array}$ \\
\hline & $31(12.3)$ & $346(35.8)$ & $5(2.5)$ & $22(4.0)$ \\
Eurobarometer (EB) & $9(3.6)$ & $22(2.3)$ & $9(4.4)$ & $22(4.0)$ \\
European Quality of Life Survey (EQLS) & $8(3.2)$ & $16(1.6)$ & $7(3.5)$ & $14(2.52)$ \\
European Social Survey (ESS) & $46(18.3)$ & $132(13.6)$ & $45(22.3)$ & $128(23.1)$ \\
European Values Studies (EVS) & $61(24.3)$ & $168(17.4)$ & $61(30.2)$ & $168(30.3)$ \\
International Social Survey Program (ISSP) & $36(14.3)$ & $156(16.1)$ & $32(15.8)$ & $134(24.2)$ \\
Italian National Election Studies (ITANES) & $32(12.7)$ & $98(10.1)$ & $16(8.0)$ & $39(7.0)$ \\
Pew Research Centre (PEW) & $28(11.1)$ & $28(2.9)$ & $27(13.4)$ & $27(4.9)$ \\
World Values Surveys (WVS) & & & & \\
& $251(100.0)$ & $966(100.0)$ & $202(100.0)$ & $554(100.0)$ \\
Total & & & & \\
\hline
\end{tabular}

Note: To estimate the domestic policy mood we have excluded from the full dataset questions on left-right selfplacement, European issues and international issues. Data on Italy in the World Values Survey are present only in the fifth wave (2005). Therefore, we included in our dataset only those questions that were administered using exactly the same wording as questions included in other surveys (in particular the European Social Survey).

Source: Eurobarometer (1981-2015); European Quality of Life Survey (2003; 2007; 2012); European Social Survey (2002; 2004; 2012); European Values Studies (1981; 1990; 1999; 2008); International Social Survey Program (1985; 1987; 1988; 1989; 1990; 1991; 1992; 1993; 1994; 1996; 1998; 2008); Italian National Election Studies (1985-2013); Pew Research Centre (2002-2015) World Values Survey (2005). 
Table A2. Dimensional analysis of preference series, 1981-2015.

\begin{tabular}{|c|c|c|c|}
\hline Abbreviated Question & House & $\mathbf{N}$ & Loading \\
\hline Government's responsibility to provide jobs & ISSP & 6 & 0.953 \\
\hline Presence of people of another race disturbing in your daily life & $\mathrm{EB}$ & 6 & 0.924 \\
\hline Presence of people of another nationality disturbing in your daily life & EB & 5 & 0.905 \\
\hline Government's responsibility to provide a decent standard of living for the unemployed & ISSP & 4 & 0.988 \\
\hline Government's responsibility to reduce income differences & ISSP & 5 & 0.876 \\
\hline Part of my income to prevent pollution & EVS & 4 & 0.845 \\
\hline Sexual relations before marriage & ISSP & 4 & 0.797 \\
\hline Presence of people of another religion disturbing in your daily life & EB & 4 & 0.773 \\
\hline More emphasis on family life & EVS/WVS & 4 & 0.756 \\
\hline More equal incomes vs larger income differences as incentive & EVS/WVS & 4 & 0.671 \\
\hline Make the recourse to abortion more difficult & ITANES & 6 & 0.590 \\
\hline Government's responsibility to reduce income differences between rich and poor & ISSP & 5 & 0.553 \\
\hline Marriage is an outdated institution & EVS/WVS & 4 & 0.561 \\
\hline Religious leaders should not try to influence how people vote in elections & ISSP & 4 & 0.552 \\
\hline Abortion can always be justified & EVS & 5 & 0.494 \\
\hline
\end{tabular}

Note: The table includes only those items that entered into the dataset in more than three separate administrations and have a loading above equal to or higher than 0.5 . 